\title{
PENGARUH PUSH DAN PULL FACTORS TERHADAP KEPUTUSAN MAHASISWA BERWISATA KE LUAR BALI
}

\author{
I Putu David Adi Saputra', I Gusti Ketut Purnaya ${ }^{2}$ \\ ${ }^{1,2}$ Institut Pariwisata dan Bisnis Internasional \\ davidsaputra22@gmail.com
}

\begin{abstract}
ABSTRAK
Tujuan penelitian ini adalah untuk mengetahui pengaruh faktor pendorong dan penarik terhadap keputusan mahasiswa berwisata ke luar Bali. Teknik pengumpulan data menggunakan kuesioner tertutup dengan menggunakan skala Likert. Teknik analisis data menggunakan deskriptif kuantitatif dan regresi linear berganda. Hasil penelitian menunjukan bahwa faktor pendorong dan penarik berpengaruh positif dan signifikan terhadap keputusan berwisata ke luar negeri dengan besaran pengaruh $43,8 \%$.
\end{abstract}

Kata kunci: Keputusan Berwisata, Faktor Pendorong, Faktor Penarik.

\section{ABSTRACT}

The purpose of the study is to find out the influence of push and pull factors on the decision of students to travel out of Bali. The data collection technique uses closed questionnaires using the likert scale. Data analysis techniques use quantitative descriptive and multiple linear regressions. The results showed that push factors and pull factors had a positive and significant effect on the decision to travel abroad with an influence of $43.8 \%$.

Keywords: Travel Decision, Push Factors, Pull Factors

\section{PENDAHULUAN}

Pariwisata merupakan sektor yang sangat sensitif terhadap perubahan baik secara internal maupun eksternal yang sangat berpengaruh terhadap jumlah dan minat wisatawan untuk mengunjungi suatu negara, wilayah/provinsi maupun daerah. Menurut Tunjungsari et al. (2017) menyatakan bahwa pariwisata membangkitkan pembangunan sarana prasarana baik itu berupa hotel, vila, losmen, bungalo dan fasilitas pendukung lainnya. Hal ini mengakibatkan pariwisata secara langsung memberikan dampak terhadap ekonomi, sosial dan budaya. 
Pariwisata dipengaruhi oleh adanya kegiatan wisata. Berbagai faktor mempengaruhi seseorang untuk melakukan kegiatan berwisata. Tujuan bepergian atau berwisata bagi kebanyakan orang adalah untuk bersenang-senang, namun tidak jarang orang memanfaatkan waktunya untuk menambah wawasan, pengetahuan, dan keterampilan tentang sesuatu. Mereka datang ke suatu tempat tidak saja hanya untuk melihat-lihat tetapi memiliki tujuan untuk melihat dan menemukan sesuatu yang berharga yang tidak mungkin didapatinya di tempat asalnya. Terdapat dua faktor yang mempengaruhi perjalanan seseorang, yaitu faktor dari dalam diri sendiri (faktor internal) seperti kesehatan, pendidikan, keuangan, dan faktor dari luar (faktor eksternal) seperti iklim, letak geografis, special event, dan lain sebagainya. Menurut Yoon dan Usyal (2003) menyatakan bahwa kegiatan berwisata dipengaruhi oleh dua faktor, yakni faktor pendorong dan penarik.

Agmasari melalui laman travel.kompas.com(2019) menyampaikan bahwa orang Indonesia cenderung mempertimbangkan lima hal ketika menentukan destinasi wisata, yaitu kebersihan, keindahan alam yang luar biasa, keamanan pribadi, kuliner setempat yang lezat, dan orang-orang lokal yang menarik dan ramah.

Hasil penelitian oleh Booking.com menunjukan bahwa terdapat lima motivasi traveling teratas oleh traveler global, yaitu meluangkan waktu untuk bersantai, meluangkan waktu untuk beristirahat, mencari pengalaman yang tidak bisa saya dapatkan di rumah, menjelajah sebanyak mungkin, dan bebas melakukan yang saya inginkan. Bagi traveler Indonesia terdapat lima motivasi traveling teratas, yakni meluangkan waktu untuk beristirahat, meluangkan waktu untuk bersantai, menghabiskan waktu bersama keluarga, menemukan sensasi dan kegembiraan, dan pengalaman yang tidak bisa saya miliki di rumah. Terdapat sepuluh destinasi wisata yang menjadi favorit traveler Indonesia pada tahun 2018, yaitu Indonesia, Singapura, Malaysia, Macau, Hongkong, Jepang, Cina, Maldives, Nepal, dan Myanmar.

Hasil penelitian Sari et al. (2018) menunjukkan adanya tujuh faktor yang mempengaruhi motivasi wisatawan muda untuk berkunjung pada destinasi wisata minat khusus yaitu faktor pendukung berwisata, faktor novelty, faktor ego and family enhancement, faktor leisure time, faktor aktualisasi diri, faktor wishfulfillment, dan faktor interaksi sosial. Dewi et al. (2017) dalam penelitiannya menunjukkan bahwa educational opportunity diikuti motif lain seperti relaxation dan play adalah faktor pendorong yang paling dominan bagi orang Bali berwisata ke luar negeri, sedangkan faktor penarik yang dominan bagi orang Bali berwisata ke luar negeri adalah cultural factors, diikuti oleh faktor natural environment dan recreation and attraction services. Aldrianto et al. (2019) menyatakan bahwa faktor kualitas pelayanan, faktor relaksasi, faktor keluarga, faktor alam adalah faktor penarik yang mempengaruhi keputusan wisatawan India berkunjung ke Bali, sedangkan faktor pendorongnya terbentuk dari interaksi sosial

Berdasarkan hal tersebut diperlukan kajian lebih mendalam terkait faktorfaktor yang mempengaruhi keputusan berwisata. Menurut Pitana dan Gayatri (2005) terdapat lima tahap penyebab keputusan seseorang melakukan wisata, yaitu 1) keinginan melakukan perjalanan, 2) pencarian dan penilaian informasi, 3) 
keputusan melakukan perjalanan, 4) persiapan perjalanan dan pengalaman wisata, dan 5) evaluasi keputusan perjalanan wisata. Banyak pandangan mengatakan bahwa yang menyebabkan wisatawan memutuskan untuk berwisata dikarenakan adanya faktor pendorong dan ada juga yang mengatakan bahwa disebabkan karena adanya faktor penarik. Para pakar mengatakan mahasiswa bisa menjadi wisatawan yang memiliki tingkat loyalitas tinggi dan sangat baik untuk membangun pariwisata di Indonesia. Penelitian ini perlu diadakan untuk mengetahui pengaruh push dan pull factors terhadap keputusan mahasiswa berwisata. Studi kasus yang diambil adalah mahasiswa yang melakukan perjalanan wisata ke luar Bali.

\section{METODE PENELITIAN}

Penelitian ini menggunakan pendekatan kuantitatif. Penelitian ini mengukur konstruk motivasi yang dipengaruhi oleh beberapa faktor yang terdiri dari variabelvariabel yang akan dijabarkan ke dalam bentuk angka-angka berupa skor yang dapat diukur. Lokasi penelitian adalah di Institut Pariwisata dan Bisnis Internasional, yang merupakan salah satu sekolah pariwisata yang jumlah mahasiswanya meningkat selama beberapa tahun terakhir dan sebagian besar mahasiswa sudah pernah melakukan perjalanan wisata ke luar Bali. Teknik pengumpulan data menggunakan kuesioner dengan skala Likert, dengan responden merupakan mahasiswa pariwisata di IPB Internasional. Teknik analisis data menggunakan deskriptif kuantitatif dan analisis regresi linear berganda. Menurut Ghozali (2011), analisis regresi linear berganda merupakan studi mengenai ketergantungan variabel terikat dengan satu atau lebih variabel bebas.

\section{HASIL DAN PEMBAHASAN}

Berdasarkan hasil penyebaran kuesioner kepada 96 responden diperoleh data profil responden berdasarkan jenis kelaminmayoritas responden berjenis kelamin laki-laki, dengan umur terbanyak adalah 18 tahun. Responden lebih memilih Jawa sebagai daerah yang dikunjungi. Rata-rata kunjungan lebih dari 3 (tiga) kali dengan biaya pengeluaran berwisata rata-rata 4 Juta. Responden berwisata dengan tujuan untuk rekreasi/ berlibur selamakurang lebih 5 hari. Responden memilih berwisata ke daya tarik wisata alam dengan melakukan kunjungan bersama keluarga. 

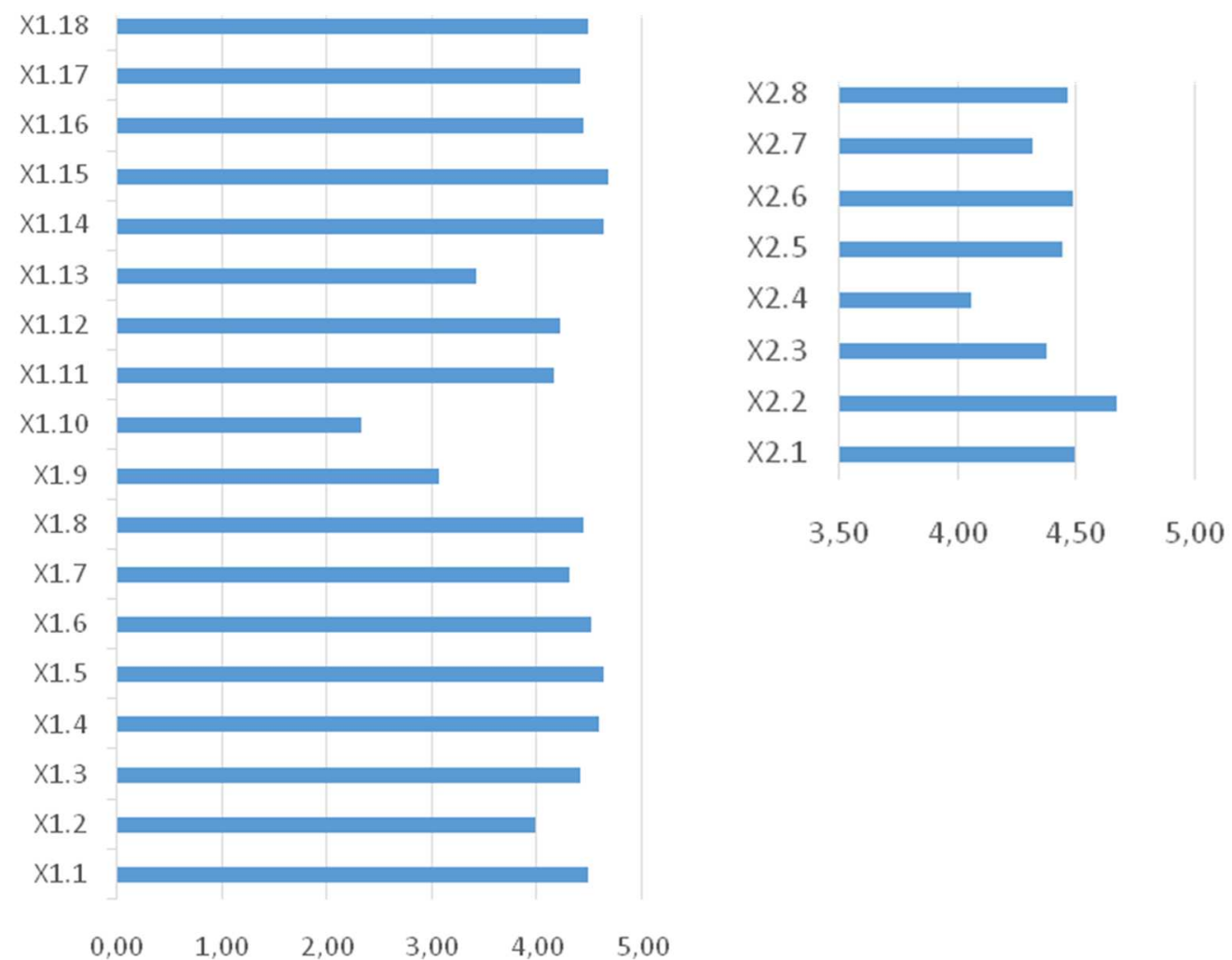

Gambar 1. Rata-rata penilaian Indikator Variabel Push dan Pull Factors

Berdasarkan hasil tabulasi ditemukan bahwa ada 4 (indikator) dari variabel push factors yang masih di bawah kategori baik, yakni indikator X1.2 (ingin terbebas dari rutinitas), X1.9 (ingin status diri naik dan diakui oleh orang lain, $\mathrm{X} 1.10$ (ingin memperlihatkan gengsi atau gaya hidup), dan X1.13 (ingin bertemu dengan orang yang bisa memberikan suasana romantis). Sedangkan variabel pull factors tidak terdapat indikator di bawah kategori baik. Hal ini dapat diasumsikan bahwa responden lebih termotivasi melakukan perjalanan wisata dikarenakan oleh pull factors.

Berdasarkan analisis regresi linear berganda ditemukan persamaan regresi antara variabel push dan pull factors terhadap keputusan mahasiswa berwisata, yakni sebagai berikut:

$$
\begin{aligned}
& Y=a+b X 1+c X 2+e \\
& Y=2,806+0,087 X 1+0,335 X 2+e
\end{aligned}
$$

Keterangan :

$\mathrm{Y}=$ Keputusan mahasiswa berwisata

$\mathrm{X} 1=$ push

$\mathrm{X} 2=$ pull 
Berdasarkan hasil persamaan dapat dijelaskan pengaruh X1 dan X2 terhadap Y sebagai berikut:

1. a (konstanta) $=2,806$ berarti apabila tidak ada X1 (bernilai 0) dan X2 (bernilai 0) maka besarnya kinerja adalah 2,806.

2. $\mathrm{b}$ (nilai koefisien regresi) $=0,087$ menyatakan bahwa dengan meningkatnya variabel push factors sebesar 1 (satu) satuan maka akan diikuti oleh meningkatnya keputusan mahasiswa berwisata rata-rata sebesar 0,087.

3. $\mathrm{c}$ (nilai koefisien regresi) $=0,335$ menyatakan bahwa dengan meningkatnya variabel pull factors sebesar 1 (satu) satuan maka akan diikuti oleh meningkatnya keputusan mahasiswa berwisata rata-rata sebesar 0,335.

Jadi dapat disimpulkan bahwa hubungan variabel push dan pull factors terhadap variabel keputusan mahasiswa berwisata ke luar Bali memiliki hubungan positif.

Tabel 1. Coefficients

\begin{tabular}{|c|l|r|r|r|r|c|}
\hline \multirow{2}{*}{} & Model & \multicolumn{2}{|c|}{$\begin{array}{c}\text { Unstandardized } \\
\text { Coefficients }\end{array}$} & $\begin{array}{c}\text { Standardized } \\
\text { Coefficients }\end{array}$ & \multirow{2}{*}{ sig. } & \\
\cline { 3 - 5 } \multicolumn{2}{|c|}{} & \multicolumn{1}{|c|}{ B } & Std. Error & \multicolumn{1}{c|}{ Beta } & & \\
\hline 1 & (Constant) & 2,806 & 2,196 & & 1,278 & 0,205 \\
\hline & X1 Total & 0,087 & 0,030 & 0,266 & 2,927 & 0,004 \\
\hline & X2 Total & 0,335 & 0,063 & 0,483 & 5,301 & 0,000 \\
\hline
\end{tabular}

Untuk mengetahui pengaruh variabel bebas $\mathrm{X}_{1}$ dan $\mathrm{X}_{2}$ terhadap variabel terikat $\mathrm{Y}$ dapat dilihat pada tabel 1. Tabel 1. Coefficients menunjukkan bahwa nilai signifikansi lebih kecil dari nilai alpha yaitu 0,05 . Dari hasil perhitungan uji $\mathrm{T}$ menggunakan nilai signifikansi diperoleh nilai 0,004dan 0,000 hal ini menunjukkan bahwa secara statistika push factors $\left(\mathrm{X}_{1}\right)$ berpengaruh signifikan terhadap keputusan mahasiswa berwisata $(\mathrm{Y})$ dan pull factors $\left(\mathrm{X}_{2}\right)$ berpengaruh signifikan terhadap keputusan mahasiswa berwisata (Y).Hal ini karena responden merupakan wisatawan Generasi Z. Generasi Z adalah generasi yang lahir tahun 1997 dan sangat mengenal dunia digital. Generasi $Z$ lebih suka menghabiskan uangnya untuk traveling. Generasi ini menganggap bahwa berwisata merupakan gaya hidup dan menjadikan kebutuhan pokok dalam hidupnya. Generasi ini juga mencoba menemukan hal-hal baru sehingga sering memilih tempat kunjungan wisata ke daya tarik wisata alam. Hal ini didukung oleh kondisi di luar Bali, daya tarik wisata yang populer dikembangkan adalah daya tarik wisata alam. Responden adalah generasi yang memiliki umur di bawah 24 tahun yang rata-rata belum menghasilkan sehingga perjalanan wisata masih bersama keluarga. Dana perjalanan wisata pun tidak terlalu besar sehingga lokasi/ tujuan wisata harus memiliki akses dan akomodasi yang murah dan nyaman. Kondisi ini juga selaras dengan segmen pasar destinasi wisata di luar Bali yang lebih berfokus ke wisatawan domestik. Transportasi udara dan darat selalu memberikan penawaran yang baik bagi wisatawan yang ingin melakukan perjalanan wisata selain ke Bali. Tentu ini memberikan peluang bagi calon wisatawan dari Bali untuk melakukan perjalanan 
wisata ke luar Bali, dengan harga yang terjangkau. Hal inilahyang menyebabkan push dan pull factors mempengaruhi secara signifikan terhadap keputusan mahasiswa berwisata ke luar Bali. Bahkan temuan ini searah dengan temuan Azman (2019) yang menyatakan bahwa push dan pull factor berpengaruh signifikan terhadap kunjungan wisatawan.

Tabel 2. Koefisien Determinasi

\begin{tabular}{|c|r|r|r|r|}
\hline Model & $\mathrm{R}$ & $\mathrm{R}$ Square & $\begin{array}{c}\text { Adjusted } R \\
\text { Square }\end{array}$ & $\begin{array}{c}\text { Std. Error of } \\
\text { the Estimate }\end{array}$ \\
\hline 1 & $0,662^{\mathrm{a}}$ & 0,438 & 0,426 & 2,041 \\
\hline
\end{tabular}

Berdasarkan Tabel 2. Koefisien Determinasi diperoleh nilai $\mathrm{R}$ square sebesar 0,438 atau sebesar $43,8 \%$. Hal ini menunjukkan bahwa kontribusi pengaruh variabel push dan pull factors terhadap keputusan mahasiswa berwisata ke luar Bali sebesar 43,8\%. Hal ini menunjukkan bahwa kontribusi pengaruh variabel push dan pull factors terhadap keputusan mahasiswa berwisata ke luar Bali memiliki pengaruh sedang dengan kriteria nilai antar 40\%-59\% (Sugiyono, 2014). Hal ini juga sejalan dengan hasil penelitian Setijograha (2020) yang menyatakan bahwa variabel push dan pull factor berpengaruh signifikan terhadap revisit intention.

\section{SIMPULAN}

Berdasarkan hasil dan pembahasan yang telah dipaparkan, maka dapat disimpulkan bahwa variabel push dan pull factors memiliki hubungan positif terhadap keputusan mahasiswa berwisata ke luar Bali. Hal ini dapat dilihat dari persamaan regresi yakni $\mathrm{Y}=2,806+0,087 \mathrm{X} 1+0,335 \mathrm{X} 2+$ e. Selain itu juga variabel push dan pull factors memiliki pengaruh signifikan terhadap keputusan mahasiswa berwisata ke luar Bali, hal ini dibuktikan dari nilai signifikansi dibawah 0,05 dengan besar pengaruhnya sebesar $43,8 \%$ yang artinya memiliki pengaruh sedang.

\section{DAFTAR PUSTAKA}

Aldrianto, Y.S.D., Sendra, IM., Sudana, IP. (2019). Faktor- Faktor yang Mempengaruhi Keputusan Wisatawan India Berkunjung Ke Bali. Jurnal IPTA, 7(2), pp.180-188.

Azman, H.A. (2019). Pengaruh Push dan Pull Factor terhadap Kunjungan Wisatawan Backpaker ke Bukitinggi. Jurnal Benefita, 4(1), pp.182-195

Dewi, N.W.A.P., Mahendra, M.S., Wiranatha, A.S. (2017). Faktor Pendorong Dan Penarik Orang Bali Berwisata Ke Luar Negeri. JUMPA, 3(2), pp. 207-223. Ghozali, I. (2011). Aplikasi Analisis Multivariat Dengan Program SPSS. Semarang: Badan Penerbit Universitas Diponogoro. 
Pitana, IG. \& Gayatri, P.G. (2005). Sosiologi Pariwisata. Yogyakarta: CV Andi Offset.

Sari, D., Kusumah, A.H.G., \& Marhanah, S. (2018). Analisis Faktor Motivasi Wisatawan Muda Dalam Mengunjungi Destinasi Wisata Minat Khusus. Journal of Indonesian Tourism, Hospitality and Recreation, 1(2).

Setijograha, V.P. (2020). Analisis Pengaruh Destination Image, Push Factors dan Pull Factors terhadap Revisit Intention Wisatawan Indonesia ke Singapura. Skripsi. Program Sarjana Manajemen Konsentrasi Pariwisata Fakultas Ekonomi Universitas Internasional Batam.

Sugiyono (2014). Metode Penelitian Pendidikan Pendekatan Kuantitatif, Kualtatif, dan R\&D. Bandung: Alfabeta.

Tunjungsari, K.R., Parwati, K.S.M., \& Semara, IM.T. (2017). Persepsi Masyarakat Kuta Terhadap Dampak Pembangunan Hotel Berkonsep City Hotel di Sunset Road Kuta Bali. Jurnal Kepariwisataan dan Hospitalitas, 1(2), pp.151-164

Yoon, Y., \& Uysal, M. (2005). An Examination Of The Effects Ofmotivation And Satisfaction On Destination Loyalty: A Structural Model. Tourism Management, 26, pp. 45-56. 